\title{
Synthesis of a Novel Bluish-Green Emitting Oxynitride $\mathrm{Ca}_{3} \mathrm{Al}_{8} \mathrm{Si}_{4} \mathrm{O}_{17} \mathrm{~N}_{4}: \mathrm{Eu}^{2+}$ Phosphor in $\mathrm{a} \mathrm{CaAl}_{4-x} \mathrm{Si}_{x} \mathrm{O}_{7-x} \mathrm{~N}_{x}$ Solid Solution System
}

\author{
Jihae Kim, Hideki Kato, Makoto Kobayashi, Yasushi Sato, Masato Kakihana* \\ Institute of Multidisciplinary Research for Advanced Materials, Tohoku University, Sendai, Japan \\ Email: ${ }^{*}$ kakihana@tagen.tohoku.ac.jp
}

Received August 8, 2013; revised September 11, 2013; accepted September 27, 2013

Copyright (C) 2013 Jihae Kim et al. This is an open access article distributed under the Creative Commons Attribution License, which permits unrestricted use, distribution, and reproduction in any medium, provided the original work is properly cited.

\begin{abstract}
Synthesis of oxynitride solid solutions $\mathrm{CaAl}_{4-x} \mathrm{Si}_{x} \mathrm{O}_{7-x} \mathrm{~N}_{x}: \mathrm{Eu}^{2+}(x=0$ - 4) was attempted by the solid state reaction (SSR) methods using $\mathrm{Si}_{3} \mathrm{~N}_{4}$ and $\mathrm{AlN}$ as nitrogen sources. The $\mathrm{Ca}_{3} \mathrm{Al}_{8} \mathrm{Si}_{4} \mathrm{O}_{17} \mathrm{~N}_{4}(x=4 / 3)$ sample with the high phase purity was obtained when AlN was used as a nitrogen source whereas the sample synthesized using $\mathrm{Si}_{3} \mathrm{~N}_{4}$ as another nitrogen source contained a $\mathrm{Ca}_{2} \mathrm{Al}_{2} \mathrm{SiO}_{7}$ impurity. Thus, it was revealed that $\mathrm{AlN}$ was a preferable nitrogen source for the synthesis of $\mathrm{Ca}_{3} \mathrm{Al}_{8} \mathrm{Si}_{4} \mathrm{O}_{17} \mathrm{~N}_{4}$ by the SSR method. The solid solutions around $x=4 / 3$ activated with $\mathrm{Eu}^{2+}$ exhibited bluish-green luminescence with emission maxima at $480 \mathrm{~nm}$ by the excitation at $250-450 \mathrm{~nm}$. Thus, the $\mathrm{CaAl}_{4-x} \mathrm{Si}_{x} \mathrm{O}_{7-x} \mathrm{~N}_{x}$ : $\mathrm{Eu}^{2+}$ solid solutions especially for $\mathrm{Ca}_{3} \mathrm{Al}_{8} \mathrm{Si}_{4} \mathrm{O}_{17} \mathrm{~N}_{4}: \mathrm{Eu}^{2+}(x=4 / 3)$ were developed as novel Eu ${ }^{2+}$-activated oxynitride phosphors capable of the excitation by the near ultraviolet (NUV) LEDs.
\end{abstract}

Keywords: Oxynitride Phosphor; $\mathrm{Eu}^{2+}$ Activator; $\mathrm{Ca}_{3} \mathrm{Al}_{8} \mathrm{Si}_{4} \mathrm{O}_{17} \mathrm{~N}_{4}: \mathrm{Eu}^{2+}$; Solid Solution

\section{Introduction}

White light-emitting diodes (LEDs) have been developing rapidly over the past decade, since its advanced properties such as long life time, high efficiency, and environmentally friendliness without use of mercury. The application of white LEDs is expanding into extensive fields such as residential lighting, medical lighting, mobile, back lights, traffic lights, emotional lighting and so on. General white LEDs are composed of a blue LED chip and yellow phosphor such as $\mathrm{Y}_{3} \mathrm{Al}_{5} \mathrm{O}_{12}: \mathrm{Ce}^{3+}$ [1]. Such combination certainly achieves generation of artificial white light; however, it is not preferable in respect of the high color temperature and the low color rendering index value $(\mathrm{CRI}<75)$ owing to the lack of red and green components. In case of residential lighting, CRI value should satisfy over 80 [2]. In order to realize such a high CRI value for the white LED, highly efficient bluegreen $(470-510 \mathrm{~nm})$ and red $(650 \mathrm{~nm})$ emitting phosphors capable of excitation by blue or NUV LEDs are demanded.

$\mathrm{Eu}^{2+}$ ions are widely used as activators in phosphors since the emission from $\mathrm{Eu}^{2+}$ attributed to the electron

${ }^{*}$ Corresponding author. transition $4 \mathrm{f}^{6} 5 \mathrm{~d}^{1} \rightarrow 4 \mathrm{f}^{7}$ is strongly affected by its surrounding environment, i.e. symmetry, covalence, bond length, crystal-field strength. In other words, the emission wavelengths from $\mathrm{Eu}^{2+}$ ions are able to be tuned from blue to red region with the selection of suitable materials as the hosts. Oxynitrides are regarded as suitable hosts since excitation and emission bands at longer wavelength are expected from the nephelauxetic effect owing to the larger covalence nature for M-N (M: metal) bonds than that for $\mathrm{M}-\mathrm{O}[3,4]$. It results in the extensive research for the $\mathrm{Eu}^{2+}$-doped oxynitrides particularly silicon-contained oxynitrides such as $\beta$-SiAlON: $\mathrm{Eu}^{2+}$ [5], $\mathrm{MSi}_{2} \mathrm{O}_{2} \mathrm{~N}_{2}: \mathrm{Eu}^{2+}(\mathrm{M}=\mathrm{Ca}, \mathrm{Sr}$, and $\mathrm{Ba})$ [6-8] and $\mathrm{Ba}_{3} \mathrm{Si}_{6} \mathrm{O}_{12} \mathrm{~N}_{2}: \mathrm{Eu}^{2+}$ [9]. Development of new oxynitride phosphors is an important research topic to enrich the phosphor library with various excitation and emission properties. Sun et al. have reported the synthesis of solid solutions between $\mathrm{CaAl}_{4} \mathrm{O}_{7}$ and $\mathrm{Ca}_{3} \mathrm{Al}_{8} \mathrm{Si}_{4} \mathrm{O}_{17} \mathrm{~N}_{4}$ [10]. Their research has attracted the authors' interest in investigation of photoluminescence properties of $\mathrm{Eu}^{2+}$-activated $\mathrm{CaAl}_{4-x} \mathrm{Si}_{x} \mathrm{O}_{7-x} \mathrm{~N}_{x}$ solid solutions.

On the other hand, homogeneous distribution of the $\mathrm{Eu}^{2+}$ activators in given host materials is one of the important factors in order to achieve high luminescence 
efficiency. Solution-based processes are potential methods to achieve homogeneous distribution of the activators [11-18]. Our research group recently has succeeded in improvements of emission intensities for oxynitride phosphors, $\mathrm{Na}_{1-x} \mathrm{M}_{x} \mathrm{AlSiO}_{4-x} \mathrm{~N}_{x}: \mathrm{Eu}^{2+}\left(\mathrm{M}=\mathrm{Mg}^{2+}, \mathrm{Ca}^{2+}\right.$, $\mathrm{Sr}^{2+}$ ) [13] and $\mathrm{Ba}_{3} \mathrm{Si}_{6} \mathrm{O}_{12} \mathrm{~N}_{2}: \mathrm{Eu}^{2+}$ [14], by the combined synthesis methods composed of the preparation of oxide precursors by solution-based method and its subsequent nitridation under ammonium atmosphere.

Based on the background described above, the synthesis of oxynitride solid solutions $\mathrm{CaAl}_{4-x} \mathrm{Si}_{x} \mathrm{O}_{7-x} \mathrm{~N}_{x}(x=0$ 4) by the SSR method and investigation of their photoluminescence properties with the $\mathrm{Eu}^{2+}$ activation were examined in the present study. In addition, the combined method involving the solution-based process and the subsequent nitridation of oxide precursor was applied for the synthesis of $\mathrm{Ca}_{3} \mathrm{Al}_{8} \mathrm{Si}_{4} \mathrm{O}_{17} \mathrm{~N}_{4}: \mathrm{Eu}^{2+}$.

\section{Experimental}

Two series of synthesis were examined for the $\mathrm{CaAl}_{4-x} \mathrm{Si}_{x} \mathrm{O}_{7-x} \mathrm{~N}_{x}: \mathrm{Eu}^{2+}$ solid solutions by a conventional solid state reaction (SSR) method as summarized in Table 1. Raw materials of $\mathrm{CaCO}_{3}, \mathrm{Eu}_{2} \mathrm{O}_{3}, \alpha-\mathrm{Al}_{2} \mathrm{O}_{3}, \mathrm{SiO}_{2}$, AlN and $\mathrm{Si}_{3} \mathrm{~N}_{4}$ were weighed and mixed thoroughly in an agate mortal with a pestle according to the ratios listed in Table 1. $2 \mathrm{~mol} \%$ of europium was substituted for calcium. The mixed powder was heat-treated at $1673 \mathrm{~K}$ for $4 \mathrm{~h}$ in a $\mathrm{H}_{2}(4 \%)$-Ar stream. For the $x=4 / 3$ sample corresponding to $\mathrm{Ca}_{3} \mathrm{Al}_{8} \mathrm{Si}_{4} \mathrm{O}_{17} \mathrm{~N}_{4}$, the combined synthesis method involving the preparation of an oxide precursor by an amorphous metal complex (AMC) method, one of solution-based methods, and its subsequent nitridation under ammonia atmosphere was also examined $[13,14]$. The oxide precursor having a composition of $(\mathrm{Ca}$, $\mathrm{Eu}) \mathrm{Al}: \mathrm{Si}=3: 8: 4$ was prepared by the AMC method. After dissolving $\mathrm{CaCO}_{3}$ in an aqueous citric acid solution, aqueous solutions of $1 \mathrm{M} \mathrm{Eu}\left(\mathrm{NO}_{3}\right)_{3}$ and $1 \mathrm{M}$ $\mathrm{Al}\left(\mathrm{NO}_{3}\right)_{3} \cdot 9 \mathrm{H}_{2} \mathrm{O}$ were added. Then, an aqueous solution of propylene glycol-modified silane (PGMS) was added.
PGMS was obtained by an alkoxy group exchange reaction for tetraethoxysilane with propylene glycol at $353 \mathrm{~K}$ in the presence of hydrochloric acid as a catalyst $[11,15]$. The mixed solutions were heated on a heating plate operated at $393 \mathrm{~K}$ with stirring to promote polymerization. The obtained polymer gel was pyrolyzed at $723 \mathrm{~K}$ for $3 \mathrm{~h}$, and subsequently at $823 \mathrm{~K}$ for $10 \mathrm{~h}$ to remove organic compounds gradually. The obtained oxide precursor, finally, was heat-treated at $1673 \mathrm{~K}$ for $4 \mathrm{~h}$ under an ammonia stream $(50 \mathrm{ml} / \mathrm{min})$.

The X-ray diffraction (XRD; Bruker AXS: D2 Phaser) was used for the phase identification. Photoluminescence spectra were measured using a fluorescence spectrometer (Hitachi: F-4500) at room temperature. Internal quantum efficiency was measured using another fluorescence spectrometer (Jasco: FP-6500) equipped with an integrating sphere.

\section{Results and Discussion}

Figure 1 shows XRD patterns of the samples in the sersies A using $\mathrm{Si}_{3} \mathrm{~N}_{4}$ as a nitrogen source as listed in Table 1. $\mathrm{CaAl}_{4} \mathrm{O}_{7}(x=0)$ was successfully obtained without any impurities. The $x=0.5$ sample contained $\mathrm{CaAl}_{4} \mathrm{O}_{7}$ and $\mathrm{Ca}_{2} \mathrm{Al}_{2} \mathrm{SiO}_{7}$ whereas the $x=1$ sample was the mixture of $\mathrm{Ca}_{2} \mathrm{Al}_{2} \mathrm{SiO}_{7}, \mathrm{Ca}_{3} \mathrm{Al}_{8} \mathrm{Si}_{4} \mathrm{O}_{17} \mathrm{~N}_{4}, \mathrm{Al}_{2} \mathrm{O}_{3}$, and $\mathrm{CaAl}_{4} \mathrm{O}_{7}$. The $x=4 / 3$ sample whose nominal composition was equal to $\mathrm{Ca}_{3} \mathrm{Al}_{8} \mathrm{Si}_{4} \mathrm{O}_{17} \mathrm{~N}_{4}$ of the known $\mathrm{Ca}-\mathrm{Al}-\mathrm{Si}-\mathrm{O}-\mathrm{N}$ compound was also crystallized in the multiphase of $\mathrm{Ca}_{3} \mathrm{Al}_{8} \mathrm{Si}_{4} \mathrm{O}_{17} \mathrm{~N}_{4}, \mathrm{Ca}_{2} \mathrm{Al}_{2} \mathrm{SiO}_{7}$, and $\mathrm{Al}_{2} \mathrm{O}_{3}$ although there is a report on the synthesis of $\mathrm{Ca}_{3} \mathrm{Al}_{8} \mathrm{Si}_{4} \mathrm{O}_{17} \mathrm{~N}_{4}$ in a single phase [10]. The $x=2$ sample showed a diffraction pattern similar to that for the $x=3 / 4$ sample. The $x=3$ sample was composed of $\mathrm{Ca}_{2} \mathrm{Al}_{2} \mathrm{SiO}_{7}$ and unknown phase while the $x=4$ sample was mixture of $\mathrm{Ca}_{3} \mathrm{Si}_{3} \mathrm{O}_{9}, \mathrm{Si}_{2} \mathrm{~N}_{2} \mathrm{O}$, and $\mathrm{Si}_{3} \mathrm{~N}_{4}$. Thus, no known Ca-Al-Si-O-N phases were formed in the samples of $x=3$ and 4 . The results in the synthesis of the samples in the series A implied the difficulties in the synthesis of the $\mathrm{CaAl}_{4-x} \mathrm{Si}_{x} \mathrm{O}_{7-x} \mathrm{~N}_{x}$ samples using $\mathrm{Si}_{3} \mathrm{~N}_{4}$ as the nitrogen source even for the known

Table 1. Compositions for $\mathrm{CaAl}_{4-x} \mathrm{Si}_{x} \mathrm{O}_{7-x} \mathrm{~N}_{x}: \mathrm{Eu}^{2+}(x=0$ - 4) solid solutions.

\begin{tabular}{|c|c|c|c|c|c|c|c|c|c|c|c|c|}
\hline \multirow[b]{2}{*}{$x$} & \multicolumn{6}{|c|}{ Series A } & \multicolumn{6}{|c|}{ Series B } \\
\hline & $\mathrm{CaCO}_{3}$ & $\mathrm{Eu}_{2} \mathrm{O}_{3}$ & $\mathrm{Al}_{2} \mathrm{O}_{3}$ & AlN & $\mathrm{SiO}_{2}$ & $\mathrm{Si}_{3} \mathrm{~N}_{4}$ & $\mathrm{CaCO}_{3}$ & $\mathrm{Eu}_{2} \mathrm{O}_{3}$ & $\mathrm{Al}_{2} \mathrm{O}_{3}$ & AlN & $\mathrm{SiO}_{2}$ & $\mathrm{Si}_{3} \mathrm{~N}_{4}$ \\
\hline 0 & 0.98 & 0.01 & 2 & 0 & 0 & 0 & 0.98 & 0.01 & 2 & 0 & 0 & 0 \\
\hline 0.5 & 0.98 & 0.01 & 1.75 & 0 & 0.125 & 0.125 & 0.98 & 0.01 & 1.5 & 0.5 & 0.5 & 0 \\
\hline 1 & 0.98 & 0.01 & 1.5 & 0 & 0.25 & 0.25 & 0.98 & 0.01 & 1 & 1 & 1 & 0 \\
\hline $4 / 3$ & 0.98 & 0.01 & 1.33 & 0 & 0.33 & 0.33 & 0.98 & 0.01 & 0.67 & 1.33 & 1.33 & 0 \\
\hline 2 & 0.98 & 0.01 & 1 & 0 & 0.5 & 0.5 & 0.98 & 0.01 & 0 & 2 & 2 & 0 \\
\hline 3 & 0.98 & 0.01 & 0.5 & 0 & 0.75 & 0.75 & 0.98 & 0.01 & 0 & 1 & 1.5 & 0.5 \\
\hline 4 & 0.98 & 0.01 & 0 & 0 & 1 & 1 & 0.98 & 0.01 & 0 & 0 & 1 & 1 \\
\hline
\end{tabular}




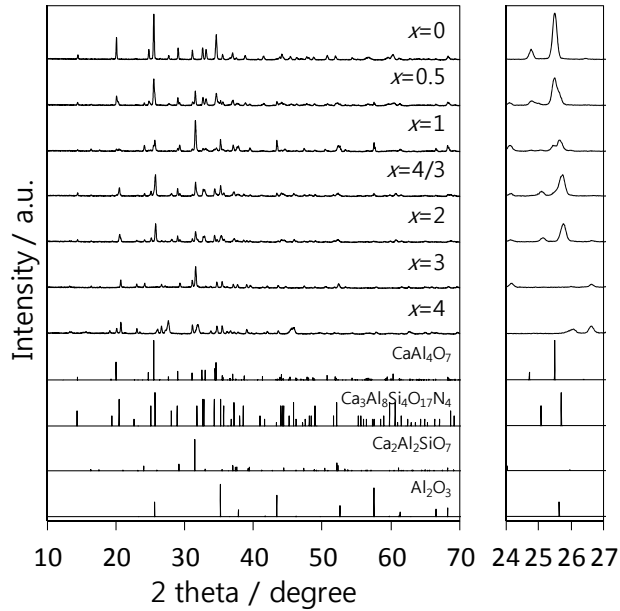

Figure 1. XRD patterns of $\mathrm{CaAl}_{4-x} \mathrm{Si}_{x} \mathrm{O}_{7-x} \mathrm{~N}_{x}: \mathrm{Eu}^{2+}$ samples (series $A$ ) synthesized by the $\mathrm{SSR}$ method using $\mathrm{Si}_{3} \mathrm{~N}_{4}$ as a nitrogen source.

compound, $\mathrm{Ca}_{3} \mathrm{Al}_{8} \mathrm{Si}_{4} \mathrm{O}_{17} \mathrm{~N}_{4}$.

Figure 2 shows XRD patterns of the samples in the series B using AlN as a nitrogen source except for the $x=$ 4 sample where the samples of $x=0$ and 4 were the same samples shown in Figure 1. The samples of $x=0.5,1$, and 2 showed the diffraction patterns similar to that of $\mathrm{Ca}_{3} \mathrm{Al}_{8} \mathrm{Si}_{4} \mathrm{O}_{17} \mathrm{~N}_{4}$, although some oxide impurities such as $\mathrm{Ca}_{2} \mathrm{Al}_{2} \mathrm{SiO}_{7}$ and $\mathrm{Al}_{2} \mathrm{O}_{3}$ were also contained. The $x=4 / 3$ sample was almost the pure phase of $\mathrm{Ca}_{3} \mathrm{Al}_{8} \mathrm{Si}_{4} \mathrm{O}_{17} \mathrm{~N}_{4}$ although the trace amount of AlN still remained. This result indicates that AlN is a preferable nitrogen source rather than $\mathrm{Si}_{3} \mathrm{~N}_{4}$ for the synthesis of $\mathrm{Ca}_{3} \mathrm{Al}_{8} \mathrm{Si}_{4} \mathrm{O}_{17} \mathrm{~N}_{4}$. The diffraction pattern of the $x=3$ sample was almost the same as the corresponding sample in the series A. It was interesting that the continuous shifts in the diffraction peaks attributed to the $\mathrm{Ca}_{3} \mathrm{Al}_{8} \mathrm{Si}_{4} \mathrm{O}_{17} \mathrm{~N}_{4}$ phase were observed for the samples of $x=1-2$ in the series B. Such shifts indicated formation of the $\mathrm{CaAl}_{4-x} \mathrm{Si}_{x} \mathrm{O}_{7-x} \mathrm{~N}_{x}$ solid solutions. In contrast to the series $\mathrm{B}$, the shifts in the diffraction peaks were not clear in the series A as shown in Figure 1. Thus, it was found that AIN was proper nitrogen source for the formation of the $\mathrm{CaAl}_{4-x} \mathrm{Si}_{x} \mathrm{O}_{7-x} \mathrm{~N}_{x}$ solid solutions than $\mathrm{Si}_{3} \mathrm{~N}_{4}$. It was assumed that the replacement of $\mathrm{Al}-\mathrm{O}$ bonds in $\mathrm{Al}_{2} \mathrm{O}_{3}$ with $\mathrm{Al}-\mathrm{N}$ bonds was a quite tough reaction in comparison with the replacement of $\mathrm{Si}-\mathrm{O}$ bonds in $\mathrm{SiO}_{2}$ with $\mathrm{Si}-\mathrm{N}$ bonds.

The authors examined photoluminescence properties for the samples of $x=1-2$ in the series $\mathrm{B}$, which contained the $\mathrm{CaAl}_{4-x} \mathrm{Si}_{x} \mathrm{O}_{7-x} \mathrm{~N}_{x}$ solid solutions as mentioned above. Figure 3 represents their photoluminescence spectra. All samples exhibited bluish-green luminescence showing broad emission bands attributed to the electron transition $4 \mathrm{f}^{6} 5 \mathrm{~d}^{1} \rightarrow 4 \mathrm{f}^{7}$ in $\mathrm{Eu}^{2+}$ with the corresponding excitation ranging from 250 to $450 \mathrm{~nm}$. The emission maxima were observed around $480 \mathrm{~nm}$ for all the sam-

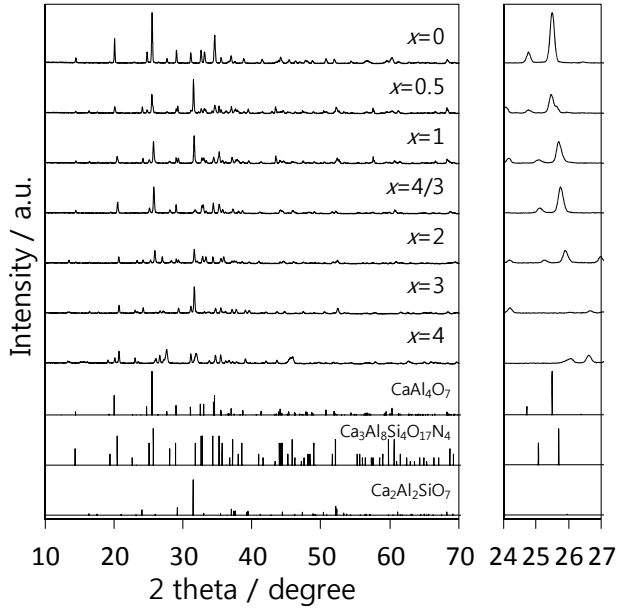

Figure 2. XRD patterns of $\mathrm{CaAl}_{4-x} \mathrm{Si}_{x} \mathrm{O}_{7-x} \mathrm{~N}_{x}: \mathrm{Eu}^{2+}$ samples (series B) synthesized by the SSR method using AIN mainly as a nitrogen source.

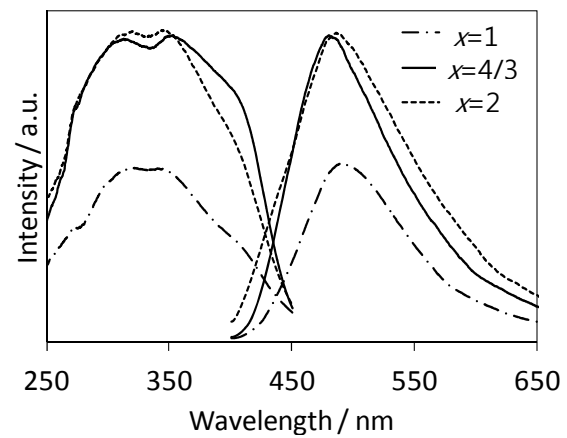

Figure 3. Photoluminescence spectra of the solid solutions $\mathrm{CaAl}_{4-x} \mathrm{Si}_{x} \mathrm{O}_{7-x} \mathrm{~N}_{x}: \mathrm{Eu}^{2+}(x=1-2)$ in the series $\mathrm{B}$.

ples. The influence of photoluminescence from $\mathrm{Ca}_{2} \mathrm{Al}_{2} \mathrm{SiO}_{7}: \mathrm{Eu}^{2+}$ contained as impurity phase in the samples of $x=1$ and 2 can be excluded because the emission intensity of $\mathrm{Ca}_{2} \mathrm{Al}_{2} \mathrm{SiO}_{7}: \mathrm{Eu}^{2+}$, which was synthesized in a single phase by the SSR method, was much lower $(<10 \%)$ than those of the present samples. In contrast to these oxynitride samples, the oxide $\mathrm{CaAl}_{4} \mathrm{O}_{7}: \mathrm{Eu}^{2+}(x=0)$ showed no emission. Thus, it has been found that the $\mathrm{Eu}^{2+}$-activated $\mathrm{CaAl}_{4-x} \mathrm{Si}_{x} \mathrm{O}_{7-x} \mathrm{~N}_{x}$ solid solutions around $x$ $=4 / 3\left(\mathrm{Ca}_{3} \mathrm{Al}_{8} \mathrm{Si}_{4} \mathrm{O}_{17} \mathrm{~N}_{4}\right)$ are novel oxynitride phosphors in the Ca-Al-Si-O-N system. Their characteristics especially for the strong excitation intensity at $400 \mathrm{~nm}$ indicate that these phosphors can be excited by the NUVLED. From the results of the synthesis with the high phase purity and the strong emission, the $x=4 / 3$ sample corresponding to $\mathrm{Ca}_{3} \mathrm{Al}_{8} \mathrm{Si}_{4} \mathrm{O}_{17} \mathrm{~N}_{4}$ was regarded as the most interesting one among them.

As described above, synthesis of the $\mathrm{Eu}^{2+}$-activated $\mathrm{Ca}_{3} \mathrm{Al}_{8} \mathrm{Si}_{4} \mathrm{O}_{17} \mathrm{~N}_{4}$ has been achieved by the SSR method using AlN as a nitrogen source. However, the SSR method is not a proper synthesis method for phosphors in respect of the distribution of activators in the host mate- 
rial. Solution-based synthesis methods are regarded as promising synthesis method for phosphors because they allow the homogeneous distribution of activators. The authors have reported that oxynitride phosphors synthesized by nitridation of oxide precursors prepared by solution-based methods exhibit stronger emission than those synthesized by the SSR methods $[13,14]$. In the present study, the authors attempted the synthesis of $\mathrm{Ca}_{3} \mathrm{Al}_{8} \mathrm{Si}_{4} \mathrm{O}_{17} \mathrm{~N}_{4}: \mathrm{Eu}^{2+}$ by the combined synthesis method that was designed with the synthesis of an oxide precursor using the AMC method of a solution-based method followed by its nitridation under ammonia atmosphere (this combined synthesis method was represented as the AMC-NH $\mathrm{N}_{3}$ method hereafter). Figure 4 shows XRD patterns of $\mathrm{Ca}_{3} \mathrm{Al}_{8} \mathrm{Si}_{4} \mathrm{O}_{17} \mathrm{~N}_{4}: \mathrm{Eu}^{2+}$ synthesized by the AMC-NH ${ }_{3}$ and SSR methods. It was confirmed that the $\mathrm{Ca}_{3} \mathrm{Al}_{8} \mathrm{Si}_{4} \mathrm{O}_{17} \mathrm{~N}_{4}$ phase was formed as the main phase in the sample synthesized by the $\mathrm{AMC}-\mathrm{NH}_{3}$ method although parasitic impurities of $\mathrm{Ca}_{2} \mathrm{Al}_{2} \mathrm{SiO}_{7}$ and $\mathrm{Al}_{2} \mathrm{O}_{3}$ were present. Figure 5 shows the excitation and emission spectra of $\mathrm{Ca}_{3} \mathrm{Al}_{8} \mathrm{Si}_{4} \mathrm{O}_{17} \mathrm{~N}_{4}: \mathrm{Eu}^{2+}$ phosphor synthesized by the $\mathrm{AMC}-\mathrm{NH}_{3}$ and SSR methods. In spite of the presence of the impurity phases the AMC- $\mathrm{NH}_{3}$ sample exhibited photoluminescence intensity comparable to the SSR sample. It would be due to homogeneous distribution of the $\mathrm{Eu}^{2+}$ activators brought by the step of the solutionbased process in the present combined synthesis method. Finally, the performance of the novel $\mathrm{Ca}_{3} \mathrm{Al}_{8} \mathrm{Si}_{4} \mathrm{O}_{17} \mathrm{~N}_{4}$ : $\mathrm{Eu}^{2+}$ phosphor was evaluated from the point of view of qualitative analysis. The AMC- $\mathrm{NH}_{3}$ sample showed $48 \%$ of an internal quantum efficiency with $76 \%$ absorption of the excitation beam at $400 \mathrm{~nm}$.

\section{Conclusion}

The oxynitride solid solutions $\mathrm{CaAl}_{4-x} \mathrm{Si}_{x} \mathrm{O}_{7-x} \mathrm{~N}_{x}$ around $x$ $=4 / 3$ were synthesized by the SSR method. It has been found that AlN is a preferable nitrogen source rather than $\mathrm{Si}_{3} \mathrm{~N}_{4}$ for the synthesis of $\mathrm{Ca}_{3} \mathrm{Al}_{8} \mathrm{Si}_{4} \mathrm{O}_{17} \mathrm{~N}_{4}$. The $\mathrm{Eu}^{2+}$-activated $\mathrm{Ca}_{3} \mathrm{Al}_{8} \mathrm{Si}_{4} \mathrm{O}_{17} \mathrm{~N}_{4}: \mathrm{Eu}^{2+}$ exhibited bluish-green lu-

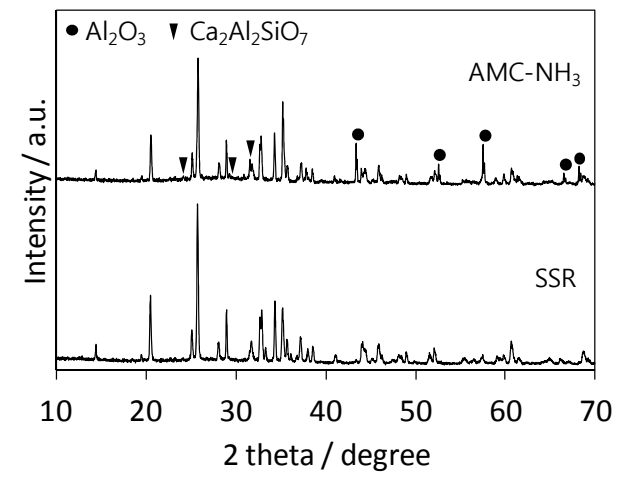

Figure 4. XRD patterns of $\mathrm{Ca}_{3} \mathrm{Al}_{8} \mathrm{Si}_{4} \mathrm{O}_{17} \mathrm{~N}_{4}: \mathrm{Eu}^{2+}$ synthesized by $\mathrm{AMC}-\mathrm{NH}_{3}$ and SSR methods.

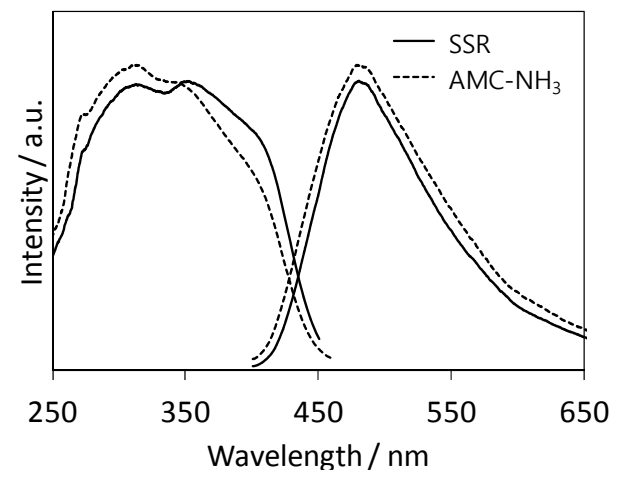

Figure 5. Photoluminescence spectra of $\mathrm{Ca}_{3} \mathrm{Al}_{8} \mathrm{Si}_{4} \mathrm{O}_{17} \mathrm{~N}_{4}$ : $\mathrm{Eu}^{2+}$ synthesized by $\mathrm{AMC}-\mathrm{NH}_{3}$ and SSR methods.

menescence at $480 \mathrm{~nm}$ by the excitation at $250-450 \mathrm{~nm}$. Thus, $\mathrm{Ca}_{3} \mathrm{Al}_{8} \mathrm{Si}_{4} \mathrm{O}_{17} \mathrm{~N}_{4}: \mathrm{Eu}^{2+}$ and its solid solutions have been developed as novel $\mathrm{Eu}^{2+}$-activated oxynitride phosphors excitable by the NUV LEDs in the present study. The $\mathrm{Ca}_{3} \mathrm{Al}_{8} \mathrm{Si}_{4} \mathrm{O}_{17} \mathrm{~N}_{4}: \mathrm{Eu}^{2+}$ phosphor was also synthesized by the combined synthesis method $\left(\mathrm{AMC}-\mathrm{NH}_{3}\right)$ involving the solution-based process. The $\mathrm{Ca}_{3} \mathrm{Al}_{8} \mathrm{Si}_{4} \mathrm{O}_{17} \mathrm{~N}_{4}: \mathrm{Eu}^{2+}$ phosphor synthesized by the $\mathrm{AMC}-\mathrm{NH}_{3}$ contained $\mathrm{Ca}_{2} \mathrm{Al}_{2} \mathrm{SiO}_{7}$ and $\mathrm{Al}_{2} \mathrm{O}_{3}$ impurities, resulted in the low phase purity of $\mathrm{Ca}_{3} \mathrm{Al}_{8} \mathrm{Si}_{4} \mathrm{O}_{17} \mathrm{~N}_{4}$. However, the AMC$\mathrm{NH}_{3}$ sample showed the emission intensity comparable to that synthesized by the SSR method. The homogeneous distribution of $\mathrm{Eu}^{2+}$ activators in the AMC- $\mathrm{NH}_{3}$ sample would contribute to the relative strong intensity of luminescence.

\section{Acknowledgements}

This work was supported by a Grant-in-Aid for Scientific Research (A) (No. 22246081) from Japan Society for the Promotion of Science, Japan.

\section{REFERENCES}

[1] S. Ye, F. Xiao, Y. Pan, Y. Ma and Q. Zhang, "Phosphors in Phosphor-Converted White Light-Emitting Diodes: Recent Advances in Materials, Techniques And Properties," Materials Science and Engineering: Reports, Vol. 71, No. 1, 2010, pp. 1-34. http://dx.doi.org/10.1016/j.mser.2010.07.001

[2] X. Li, J. Budai, F. Liu, J. Howe, J. Zhang, X. Wang, Z. $\mathrm{Gu}, \mathrm{C}$. Sun, R. Meltzer and Z. Pan, "New Yellow $\mathrm{Ba}_{0.93} \mathrm{Eu}_{0.07} \mathrm{Al}_{2} \mathrm{O}_{4}$ Phosphor for Warm-White Light-Emitting Diodes through Single-Emitting-Center Conversion," Light: Science \& Applications, Vol. 2, 2013, p. e50. http://dx.doi.org/10.1038/1sa.2013.6

[3] R. Xie and N. Hirosaki, "Silicon-Based Oxynitride and Nitride Phosphors for White LEDs-A Review," Science and Technology of Advanced Materials, Vol. 8, No. 7-8, 2007, pp. 588-600.

http://dx.doi.org/10.1016/j.stam.2007.08.005

[4] R. Xie, N. Hirosaki, Y. Li and T. Takeda, "Rare-Earth 
Activated Nitride Phosphors: Synthesis, Luminescence and Applications," Materials, Vol. 3, No. 6, 2010, pp. 3777-3793. http://dx.doi.org/10.3390/ma3063777

[5] S. Yamada, H. Emoto, M. Ibukiyama and N. Hirosaki, "Properties of SiAlON Powder Phosphors for White LEDs," Journal of the European Ceramic Society, Vol. 32, No. 7, 2012, pp. 1355.-1358. http://dx.doi.org/10.1016/j.jeurceramsoc.2011.05.050

[6] X. Song, R. Fu, S. Agathopoulos, H. He, X. Zhao and S. Zhang, "Photoluminescence properties of $\mathrm{Eu}^{2+}$-activated $\mathrm{CaSi}_{2} \mathrm{O}_{2} \mathrm{~N}_{2}$ : Redshift and concentration quenching," Journal of Applied Physics, Vol. 106, No. 3, 2009, Article ID. 033103. http://dx.doi.org/10.1063/1.3190522

[7] R. Liu, Y. Liu, N. Bagkar, and S. Hu, "Enhanced Luminescence of $\mathrm{SrSi}_{2} \mathrm{O}_{2} \mathrm{~N}_{2}$ : Eu ${ }^{2+}$ Phosphors by Codoping with $\mathrm{Ce}^{3+}, \mathrm{Mn}^{2+}$, and $\mathrm{Dy}^{3+}$ Ions," Journal of Applied Physics, Vol. 91, No. 6, 2007, Article ID. 061119.

http://dx.doi.org/10.1063/1.2768916

[8] B. Yun, T. Horikawa, H. Hanzawa and K. Machida, "Preparation and Luminescence Properties of Single-Phase $\mathrm{BaSi}_{2} \mathrm{O}_{2} \mathrm{~N}_{2}: \mathrm{Eu}^{2+}$, a Bluish-Green Phosphor for White Light-Emitting Diodes" Journal of The Electrochemical Society, Vol. 157, No. 10, 2010, pp. J364-J370. http://dx.doi.org/10.1149/1.3479763

[9] K. Komeya, Y. Cheng, J. Tatami and M. Mitomo, "New Green Phosphor $\mathrm{Ba}_{3} \mathrm{Si}_{6} \mathrm{O}_{12} \mathrm{~N}_{2}$ :Eu for White LED: Crystal Structure and Optical Properties," Key Engineering Materials, Vol. 403, 2009, pp. 11-14. http://dx.doi.org/10.4028/www.scientific.net/KEM.403.1 1

[10] W. Y. Sun and T. S. Yen, "Subsolidus Phase Relationships in Part of the System Si, AI, Ca/N, O," Ceramics International, Vol. 14, No. 4, 1988, pp. 199-205. http://dx.doi.org/10.1016/0272-8842(88)90022-3

[11] K. Yoshizawa, H. Kato, M. Kakihana, "Synthesis of $\mathrm{Zn}_{2} \mathrm{SiO}_{4}: \mathrm{Mn}^{2+}$ by Homogeneous Precipitation Using Propylene Glycol-Modified Silane," Journal of Materials Chemistry, Vol. 22, No. 33, 2012, pp.17272-17277. http://dx.doi.org/10.1039/c2jm33056c
[12] M. Kim, M. Kobayashi, H. Kato and M. Kakihana, "Enhancement of Luminescence Properties of a $\mathrm{KSrPO}_{4}$ : $\mathrm{Eu}^{2+}$ Phosphor Prepared Using a Solution Method with a Water-Soluble Phosphate Oligomer," Journal of Materials Chemistry C, Vol. 1, No. 25, 2013, pp. 5741-5746. http://dx.doi.org/10.1039/c3tc31121j

[13] J. Kim, H. Kato and M. Kakihana, "Control of NaAl$\mathrm{SiO}_{4}: \mathrm{Eu}^{2+}$ Photoluminescence Properties by Charge-Compensated Aliovalent Element Substitutions," Journal of Information Display, Vol. 13, No. 3, 2012, pp. 97-100. http://dx.doi.org/10.1080/15980316.2012.691079

[14] C. Yasushita, H. Kato and M. Kakihana, "Synthesis of an Oxynitride-Based Green Phosphor $\mathrm{Ba}_{3} \mathrm{Si}_{6} \mathrm{O}_{12} \mathrm{~N}_{2}: \mathrm{Eu}^{2+}$ via an Aqueous Solution Process Using Propylene GlycolModified Silane," Journal of Information Display, Vol. 13, No. 3, 2012, pp. 107-111. http://dx.doi.org/10.1080/15980316.2012.692725

[15] Y. Suzuki and M. Kakihana, "Preparation of Water Soluble Silicon Compound and its Application for Synthesis of $(\mathrm{Y}, \mathrm{Ce}, \mathrm{Gd})_{2} \mathrm{SiO}_{5}$ Blue Emission Phosphor," Journal of the Ceramic Society of Japan, Vol. 117, No. 3, 2009, pp. 330-334. http://dx.doi.org/10.2109/jcersj2.117.330

[16] M. Kakihana, "Synthesis of High-Performance Ceramics Based on Polymerizable Complex Method," Journal of the Ceramic Society of Japan, Vol. 117, No. 8, 2009, pp. 857-862. http://dx.doi.org/10.2109/jcersj2.117.857

[17] N. Naruse, K. Tomita, M. Iwaoka and M. Kakihana, "Synthesis and Morphology Control of $\mathrm{YBO}_{3}: \mathrm{Tb}^{3+}$ Green Phosphor by Precipitation from Homogeneous solution" Journal of the Ceramic Society of Japan, Vol.121, No. 6, 2013, pp. 502-505. http://dx.doi.org/10.2109/jcersj2.121.502

[18] Y. Luo, D. S. Jo, K. Senthil, S. Tezuka, M. Kakihana, K. Toda, T. Masaki and D. H. Yoon, "Synthesis of High Efficient $\mathrm{Ca}_{2} \mathrm{SiO}_{4}$ : $\mathrm{Eu}^{2+}$ Green Emitting Phosphor by a Liquid Phase Precursor Method," Journal of Solid State Chemistry, Vol. 189, 2012, pp. 68-74. http://dx.doi.org/10.1016/j.jssc.2011.11.046 